\title{
HUMOUR IN THE AMERICAN AND BRITISH COMEDYEPISODES: A DISCOURSE ANALYSIS STUDY
}

\author{
Amna Abdul Kareem Mohammed, Supervised by: Asst.Prof. Bushra Nima Rashid \\ College of Education Ibn-Rushd for Humanities, University of Baghdad
}

DOI: $10.37648 /$ ijrssh.v10i02.005

Received:15 $5^{\text {th }}$ December, 2019; Accepted:20 ${ }^{\text {th }}$ January, 2020; Published: $10^{\text {th }}$ February, 2020

\begin{abstract}
:
The present study investigates humour in the American 'Friends' and the British 'The Vicar of Dibley' sitcoms from a discourse analysis study point of view. This study is expected to answer the following questions: Does humour represent direct or indirect speech acts? What are the different types of humour used by the characters in the selected sitcoms under study? This study aims at investigating humour in terms of Searle's Speech Acts Theory to show whether humour is direct or indirect speech act, and showing the role played by different cultures in using, understanding and enjoying humour. The study hypothesizes that: there is a relation between humour and speech acts; humour is being used more among the British people rather than the American ones. The study combines four models of analysis concerning forms and functions of humour. There is also a relation between humour and speech acts because humour sometimes indicates direct or indirect speech acts. Moreover, it seems obvious that the forms (types) of humour in the American situation comedy 'Friends' are more intensive than the forms of humour found in the British sitcom 'The Vicar of Dibley'.

Keywords: Discourse Analysis, Pragmatics, Humour, sitcoms
\end{abstract}

\section{INTRODUCTION}

Principally, humour is existed in almost all kinds of personal and communicative relationships, thus, it is considered as a major part of human nature characteristics. People exchange humorous expressions in everyday meeting because humour has a remarkable effect on people's daily relationships, consequently, it removes boredom and makes speech interesting and fruitful. (Lefcourt, 2001; as cited in Martin, 2007, p. 329). The use of humour is noticed in different fields such as comics, "mass media, radio, TV, stand-up comedy, and in sitcoms." (Martin, 2010). It is shown in the form of presenting sarcastic phrases, giving comments that represent wit, or saying and writing jokes. (ibid).
Humour is delineated as a complex phenomenon because it embraces verbal and non-verbal languages. The reason behind using it is to show a personal experience of the person or to provide communicative goals. Humour is sometimes intentionally used for the sake of attracting someone's attention, or for attacking an opposing side, or it is used unintentionally. The phenomenon of humour is related with different factors such as sex, age, civilization, context, participants, social group, era and cultures. So, all these factors have an effect on humour usage. (Ermida, 2008).

\section{THEORETICAL BACKGROUND}

Humour is characterized as having a significant impact to make life and communication vibrant and interesting. It is almost the only thing that all individuals with different ages and genders feel joyful depending on the 
type and characteristics of a communicative event, which is supposed to be positive because a touch of humour removes psychological barriers. It is widely acknowledged and noticed that if someone laughs and says jokes with another, this means that there is a connection between the two persons. (Chadwick and Platt, 2018: 1-5).

\subsection{Text, Context and Situation}

Text is defined by Crystal (2011: 481), as an instance of language that is used to describe and analyze something. Texts may denote written and spoken data, the second includes for instance, "conversation, monologues, rituals, and so on" (ibid, p.481-482). Regarding context, Widdowson (2007:128) defines it as "those aspects of extralinguistic reality that are taken to be relevant to communication." Such a definition focuses on the relevant features of the situations rather than the situation itself. In other words, he pays no attention to the external circumstances which encompass the text, but the ways he represents them in his mind. While context is likened as a marvellous play or genre, situation "is like the scene played by actors, with their props, dispositions, orientations, histories, and relationships." Thus, situation is the general atmosphere that is influenced by the context. (Keith, 2015: 107).

\subsection{Pragmatics: Language and Language Use}

It is worth and needful to define the field of pragmatics to understand it and to pave the way to its theories. Pragmatics is a branch of linguistics that is related with studying the meaning as produced by the speaker or writer and comprehended by the listener or reader. It is concerned with the meaning of utterances conveyed by individuals.Thus, it is "the study of speaker meaning." (Yule, 1996: 3) The field of pragmatics includes how context has an effect on the interpretation of discourse. Hence, it is the study of contextual meaning. It also investigates how listeners or readers infer or understand from what is unsaid. Therefore, it basically studies what is communicated. (ibid) Thus, to understand what is behind the sentence, to think deeply about any particular utterance, to reach the real meaning behind the speaker's idea and to understand the unclear meaning, one has to make use of pragmatics. (M. Anand, 2014: 13).

\subsection{Discourse Analysis: An Overview}

Discourse analysis is regarded as being an old and a new area of study. It can be traced back to the study of language, public speech and literature before 2000 years ago. The main historical source is the art of good speaking, that is classical rhetoric. However, in the 1960s and early 1970s, discourse analysis gets interest in various branches of linguistics, philosophy, semiotics, anthropology, sociology, literary theory, communication, education, and psychology, (Van Dijk,1985: 1-2).

As a result, discourse analysis appears in many forms because it has a developing nature, in addition to its various disciplinary origins. Consequently, this is considered as an advantage of the field. Discourse analysis is not restricted to any single field and previous ideas and methods are pervaded across fields, nor they are bound by traditions. The verb discourse means "to travel across a course". This verb is likened to discourse analysis in that it also travels across different disciplines. (Wood and Kroger, 2000:18).

\subsection{Humour and itsHistorical Background}

Lynch (2002: 55) indicates that "all humour is fundamentally a communicative activity" he adds more by saying that "humour is an intended or unintended message interpreted as funny, at its most basic level. From an etymological perspective, the origin of the word humour is traced back to Latin; it is originated (arisen) from the Latin word 'umor', that means 'liquid'. Historically speaking, the term humour reverts back to the olden ages. Medicine in the medieval times used to use the word humour to indicate four kinds of liquids: 'blood', 'Phlegm', 'yellow bile' and 'black bile'. All these four fluids are supposed to be at the corresponding level for a person to have a humorous mood and a good health. In the $16^{\text {th }}$ century, the phrase 'good humour' shows the 'cheerfulness' of the individual's mentality, that is, how a person is mentally joyful. The comic sense of humour usage in Europe began too late; specifically, in the late $17^{\text {th }}$ century and this is the reason behind the difficulty of giving a 
thorough definition of humour at that time. Commenting on this, the kind of humour was something connected with the deviation from the conventional social standards. Afterwards, through its evolution, it embraced the sense of peculiarity which guides to laughter. (Ermida, 2008).

\subsection{Theories of Humour}

In philosophy, humour theories have persisted on being a major and a significant source of literature for many researchers across the years. A tripartite categorization has been made of three theories that have been broadly utilized by researchers in humour studies. These theories are Superiority, Relief and Incongruity.

\subsection{Forms of Humour}

People come across a great deal of different forms (types) of humour in the normal everyday events. These forms of humour are presented by various means and for various reasons. Martin (2007:11) points out that humour is categorized into three broad forms which are jokes, spontaneous conversational humour, and accidental or unintentional humour.

\subsubsection{Jokes}

Jokes are explained by Martin (2010:12) by saying that in any typical conversation, people create funny environment by saying jokes, that are described as short and entertaining stories which end in a punch line. Sometimes they are referred to as canned jokes. A canned joke is a joke which has been utilized originally and firstly in books, jokes collections, ...etc. in a way that is similar to that is used by another speakers or writers. According to The joke is composed of a setup and a punch line. The setup embraces all except the last sentence. This part makes the listener to think of a number of expectations concerning the interpretations of the situation. The punch line creates a shift in meaning in a playful and a sudden way. (ibid.).

\subsubsection{Spontaneous Conversational Humour}

Long and Graesser (1988; 35-60 as cited in Martin, 2007:13) present eleven categories of spontaneous conversation humour, each one of them is different from the other based on the intention or uses of humour. They are explained below:

\section{Irony}

Irony is defined as a literary device that means there is an incongruity between what is said or done and what is meant or understood. Long and Graesser (1988; 35-60 as cited in Martin, 2007:13).

\section{Satire}

Satire is considered to be an offensive humour used to make fun of policy or social institutions, Long and Graesser (1988; 35-60 as cited in Martin, 2007:13).

\section{Sarcasm}

Sarcasm is defined as a type of offensive humour that concerns individuals rather than institutions. Long and Graesser (1988; 35-60 as cited in Martin, 2007:13).

\section{Overstatement and Understatement}

These terms are defined as forms of speech where the speaker uses a greater utterance or lesser utterance more than what is anticipated. Long and Graesser (1988; 35-60 as cited in Martin, 2007:13).

\section{Self-deprecation}

This form of humour relies on the observation of a negative point about the individual who is conveying this observation. Self-deprecating humour is used by speakers to keep away from being arrogant people and to make the audience know them. Long and Graesser (1988; 35-60 as cited in Martin, 2007:13).

\section{6. $\quad$ Teasing}

Teasing is depicted as a humorous remark that is addressed to the hearer's personal look, habit, and qualities. It is unlike sarcasm because here the intention of the speaker is not to offend or insult the hearer for real. Long and Graesser (1988; 35-60 as cited in Martin, 2007:13).

7. Replies to rhetorical questions

The speaker who asks a rhetorical question does not expect the listener to give a reply. So, giving an answer to a rhetorical question creates a surprise 
for the speaker because of his/her reverse conversational expectation and this generates an incongruity of expectations. Long and Graesser (1988; 35-60 as cited in Martin, 2007:13).

8. Clever replies to serious statements

Sometimes, the interlocutor says witty, incompatible, or senseless replies to a previous statement or question that is said with serious meaning. This serious statement is intentionally misunderstood so that the interlocutor replies with a meaning that is different from the intentional one. Long and Graesser (1988; 35-60 as cited in Martin, 2007:13).

9. Double entendres

Double entendre is regarded as a figure of speech in which the speaker says a spoken phrase with intention that this phrase can be perceived in two or double ways. The first meaning suggests something explicit or direct, but the second one suggests something unsuitable or sexual. Long and Graesser (1988; 35-60 as cited in Martin, 2007:13).

10. Transformations of frozen expression

When famous words, proverbs, or clichés are converted by the speaker into new statements, such as "Hair today, gone tomorrow" when a bald man is complaining. Long and Graesser $(1988 ; 35-60$ as cited in Martin, 2007:13).

\section{Pun}

A pun is denoted when a speaker uses a word which gives a humorous second meaning. A homophone is the basis of pun. That is, a word that sounds the same but with different meaning. Long and Graesser (1988; 35-60 as cited in Martin, 2007:13).

Other group of types of humour is presented by Audrieth (1998) in his book The Art of Using Humor. They are: -

\section{Banter}

Regarding Audrieth (1998: 6), banter can be defined as a friendly and kind reciprocation of teasing or witty comments between friends.

\section{Blunder}

In Audrieth's The Art of Using Humor, blunder is defined as wit which depends on an individual who commits a mistake that in turn makes it seem foolish. There are different types of blunder. Some of them are dependent on wrong identities of people and take their source from the failure of noticing differences between people caused by surrounding circumstances. Other blunders are dependent on situations where a person releases himself after performing something stupid by using wit. (Audrieth,1998: 7).

\section{Chain}

According to Audrieth (1998: 10), the chain is a type of humour which is composed of a series of words connected together. It can be chronological, linguistic, geographical, etc.

\section{Freudian Slip}

Freudian slip is defined by Audrieth (1998: 12) as a funny statement which looks accidental, but it is assumed that the deep psychological disorder of the speaker is a rich source for its creation.

\section{Irony}

Irony is one of the essential components of humor. It is when the speaker uses words to deliver something which is different from (the opposite) the literal meaning of these words. (Audrieth,1998: 12).

\section{Mistaken identity}

Mistaken identity is the standard expression used for denoting a humorous confusion between one thing and another, or between one human and another, because of similarities, mutual characteristics, or evocative circumstances. (Audrieth,1998: 14). 


\section{Relapse}

The comic relapse is the equivalent to the comic recovery. A person who says and does something that suggests smartness or cunning will find out that it is actually a blunder. (Audrieth,1998: 16).

\section{Repartee}

Audrieth (1998: 16) states that wit comprises from repartee. So, repartee is considered as a part of wit that includes replies and retorts. Repartee consists of insult, double insult, parallel and reversible.

\subsubsection{Unintentional Humour}

Unintentional humour is described by Wyer and Collins (1992; as cited in Martin, 2010: 11) as 'utterances' or 'actions' that are made by people without thinking or unconsciously and still have capability to create fun or humour. Martin (2007: 14) and Nilsen and Nilsen (2000: 14) identify two categories of unintentional humour or 'accidental humor' which are accidental physical humour and accidental linguistic humour. Accidental physical humour comprises from minor actions come across people by chance such as a person slips on a banana peel or when a drink spills on a shirt. On the other hand, accidental linguistic humour is appeared from the unconscious errors done by the participants in a particular conversation (Martin, 2007: 14).

\subsection{Functions of Humour}

Humour has different social functions in addition to its entertainment function. The main functions of humour in an exchange of speech are the effects that the interlocutor may accomplish immediately by using humorous phrases or texts in his/her discourse (Attardo, 1994: 322). As stated in Attardo's book Linguistic Theories of Humor (1994: 323-329), the functions of humour on the can be categorized into four sorts.

\subsubsection{Social Management}

The function of humour which is social management includes all the instances in which humour is utilized as a tool to create group interaction and support the group bonding or group rejection. These instances are social control, social norms conveyance, ingratiation, discourse management, common ground establishment, cleverness, social play, and repair.

\subsubsection{Decommitment}

Decommitment is defined by Kane et al (in Attardo 1994: 325) as refusing any hurtful intent for an action and for the interlocutor in order to affirm that $\mathrm{s} / \mathrm{he}$ did not intend to maintain or to carry out truly or in a serious way an action which had been initially began. The corner stone of the decommitment function is that humorous speech can be retracted. That is, without loss of face, the speaker can go back from his/her utterance (Brown and Levinson in Attardo, 1994: 325). Decommitment strategies include probing and salvaging.

\subsubsection{Mediation}

Humour is used either to present or to perform embarrassing or aggressive interactions. In a nutshell, humour is depicted as a mediating device. Because these embarrassing and aggressive interactions are not always attached to the maxim of quality, the speaker can say that he is irresponsible for what $\mathrm{s} / \mathrm{he}$ is saying. Put it differently, the speaker can say that s/he was just kidding even that s/he say something aggressive or serious so that to mediate a particular situation (Mulkay in Attardo,1994: 327).

\subsubsection{Defunctionalization}

Humour, especially nonsense humour or puns, can in some cases be seen as a defunctionalization of language (Guiraud in Attardo, 1994: 328). Defunctionalized language is language that is not used for transmission of information, but for playful purposes. This theory comes from Freud's remark which says that humorous use of language is close to children's pleasure in playing with words.

\section{DATA COLLECTION}

The data chosen by the researcher are two situation comedies, American and British. The American data is 'Friends' and the British one is 'The Vicar of Dibley'. The researcher has chosen two seasons; the first season and the third one from each situation comedy, taking into consideration the era and the length of the pages. Both sitcoms aired in 1994. 


\subsection{The American Situation Comedy 'Friends'}

Friends is a situation comedy or a type of comedy that is involved a fixed number of characters who continue from one episode to another. It is created by Marta Kauffmann and David Crane, that is aired in 1994 to 2004 in the USA. It came to be one of the most famous sitcoms, winning many awards.

\subsubsection{The Plot}

The sitcom is about six characters in their 20 years who live in New York City. They are Rachel (characterized by Jennifer Aniston), Monica (Courtney Cox), Phoebe (Lisa Kurow), Chandler (Matthew Perry), Joey (Matt Le Blanc) and Ross (David Schwimmer). Their setting is almost either in the café called Central Perk or in their apartments. They usually chat about different kinds of topics and especially about love and making relationships. There are no characters who are more prominent among those six characters. Humour is the essential component of their conversations. The characters do their successful performance in creating universal humour which is belonged to the writers as well.

\subsection{The British Situation Comedy 'The Vicar of Dibley'}

The Vicar of Dibley is a situation comedy or a type of comedy that is involved a fixed number of characters who continue from one episode to another. It is created by Richard Curtis and Paul Mayhew-Archer, that is aired in 1994 to 2007 in the UK. It takes third level in a BBC poll of Britain's Best Sitcom.

\subsubsection{The Plot}

The sitcom is about eight characters in different ages who live in a village called Dibley in Oxfordshire. They are Geraldine (characterized by Dawn French), David (Cary Waldhorn), Owen (Roger Lloyd-Pack), Jim
(Trevor Peacock), Frank (John Bluthal), Hugo (James Fleet), Alice (Emma Chambers) and Letitia (Liz Smith). Their setting is almost either in the parish hall or in Geraldine's living room. They are also gathered in David's sitting room. They usually chat different kinds of topics and especially about church business and decisions concerning the village. Geraldine Granger is more prominent character than the other seven characters, but they are all the main characters in this sitcom. Geraldine becomes the vicar of Dibley when the old vicar passes away. This surprises the parishioners because this is the first time to experience a woman as a vicar.

\subsection{The Eclectic Model}

First, the researcher is going to analyze the forms of humour depending on Martin (2007) including Long and Graesser's (1988) forms mentioned in Martin's book and Audrieth's (1998) types. Second, the function of humour is being analysed depending on Attardo's (1994) classification. All these models are mentioned in chapter two. Then, Searle's model (1969) is going to be adopted by the researcher to show whether the humorous expression is direct and indirect speech acts.

\section{DATA ANALYSIS AND DISCUSSION OF THE RESULTS}

This section tackles the analysis of the data chosen by the researcher. The data are two episodes from two situation comedies, American and British. The American situation comedy is 'Friends' and the British one is 'The Vicar of Dibley'. They are both started and displayed in the same year. So, the researcher is going to analyze the data according to the eclectic model chosen where the data are to be analyzed according to the form of humour, strategy used (whether the form of humour is direct or indirect with its specific types), and the function of humour. 


\subsection{The Analysis of the American Sitcom 'Friends'}

\section{Season 1}

Episode 1: The One Where Monica Gets a New Roommate

Table (4.1) The Analysis of Humour in 'Friends'

\begin{tabular}{|c|c|c|c|c|c|}
\hline $\mathbf{P}$. & L. & Data & $\begin{array}{l}\text { Form of } \\
\text { Humour }\end{array}$ & Strategy Used & Function of Humour \\
\hline 1 & 3 & $\begin{array}{l}\text { Joey: C'mon, you're } \\
\text { going out with the } \\
\text { guy! There's gotta } \\
\text { be something } \\
\text { wrong with him! }\end{array}$ & Teasing. & $\begin{array}{l}\text { Indirect } \quad \text { speech } \\
\text { act:representative/assertive,concluding. }\end{array}$ & Social management. \\
\hline 1 & 4 & $\begin{array}{l}\text { Chandler: So does } \\
\text { he have a hump? A } \\
\text { hump and a } \\
\text { hairpiece? }\end{array}$ & Banter. & $\begin{array}{l}\text { Direct speech act: } \\
\text { representative/assertive, estimating. }\end{array}$ & $\begin{array}{l}\text { Social management and } \\
\text { decommitment. }\end{array}$ \\
\hline 1 & 5 & $\begin{array}{l}\text { Phoebe:Wait, does } \\
\text { he eat chalk? }\end{array}$ & $\begin{array}{l}\text { Banter and } \\
\text { mistaken } \\
\text { identity. }\end{array}$ & $\begin{array}{l}\text { Indirect speech } \quad \text { act: } \\
\text { representative/assertive, } \\
\text { directive, warning. }\end{array}$ & $\begin{array}{l}\text { Social management and } \\
\text { mediation. }\end{array}$ \\
\hline 1 & 7 & $\begin{array}{l}\text { Phoebe: Just, } \\
\text { 'cause, I don't want } \\
\text { her to go through } \\
\text { what I rent } \\
\text { through with Carl- } \\
\text { oh! }\end{array}$ & $\begin{array}{l}\text { Self- } \\
\text { deprecation, } \\
\text { blunder and } \\
\text { mistaken } \\
\text { identity. }\end{array}$ & $\begin{array}{l}\text { Indirect speech } \quad \text { act: } \\
\text { representative/assertive, } \\
\text { directive, warning. }\end{array}$ & Social management. \\
\hline 1 & 10 & $\begin{array}{l}\text { Chandler: Sounds } \\
\text { like a date to me. }\end{array}$ & $\begin{array}{l}\text { Clever reply to } \\
\text { serious } \\
\text { statement and } \\
\text { banter. }\end{array}$ & $\begin{array}{l}\text { Indirect speech } \\
\text { representative/assertive, supposing or } \\
\text { doubting. }\end{array}$ & Social management. \\
\hline 1 & 15 & $\begin{array}{ll}\text { Chandler:Then I } & \text { I } \\
\text { look down, and I } \\
\text { realize there's a } \\
\text { phone... there. }\end{array}$ & $\begin{array}{l}\text { Self- } \\
\text { deprecation. }\end{array}$ & $\begin{array}{l}\text { Indirect speech } \\
\text { representative/assertive, describing }\end{array}$ & Social management. \\
\hline 1 & 16 & Joey: Instead of...? & Banter. & $\begin{array}{l}\text { Indirect speech act: } \\
\text { representative/assertive, estimating. }\end{array}$ & Decommitment. \\
\hline 1 & 17 & $\begin{array}{l}\text { Chandler: That's } \\
\text { right. }\end{array}$ & Banter. & $\begin{array}{l}\text { Direct speech } \\
\text { representative/assertive, affirming. }\end{array}$ & Social management. \\
\hline 2 & 25 & $\begin{array}{l}\text { Joey: This guy says } \\
\text { hello, I wanna kill }\end{array}$ & $\begin{array}{l}\text { Banter and } \\
\text { overstatement. }\end{array}$ & $\begin{array}{l}\text { Indirect speech act: expressive, } \\
\text { criticizing. }\end{array}$ & Social management. \\
\hline
\end{tabular}




\begin{tabular}{|c|c|c|c|c|c|}
\hline & & myself. & & & \\
\hline 2 & 29 & Chandler: Cookie? & $\begin{array}{l}\text { Clever reply to } \\
\text { serious } \\
\text { statement and } \\
\text { relapse. }\end{array}$ & $\begin{array}{l}\text { Direct speech act: commissive, } \\
\text { offering. }\end{array}$ & Social management. \\
\hline 2 & 34 & $\begin{array}{l}\text { Phoebe: Ooh! Oh! } \\
\text { (She starts to pluck } \\
\text { at the air just in } \\
\text { front of Ross.) }\end{array}$ & $\begin{array}{l}\text { unintentional } \\
\text { humour/ } \\
\text { accidental } \\
\text { physical } \\
\text { humour. }\end{array}$ & _. & - \\
\hline 2 & 39 & $\begin{array}{l}\text { No I don't, to hell } \\
\text { with her, she left } \\
\text { me! }\end{array}$ & $\begin{array}{l}\text { Self- } \\
\text { deprecation } \\
\text { and Freudian } \\
\text { slip. }\end{array}$ & $\begin{array}{l}\text { Indirect } \quad \text { speech } \\
\text { representative/assertive, }\end{array}$ & Social management. \\
\hline 2 & 40 & $\begin{array}{l}\text { And you never } \\
\text { knew she was a } \\
\text { lesbian... }\end{array}$ & Banter. & $\begin{array}{l}\text { Indirect speech } \\
\text { representative/assertive, informing and } \\
\text { affirming. }\end{array}$ & Social management. \\
\hline 3 & 51 & $\begin{array}{l}\text { And I just want a } \\
\text { million dollars! (He } \\
\text { extends his hand } \\
\text { hopefully.) }\end{array}$ & $\begin{array}{l}\text { Clever reply to } \\
\text { serious } \\
\text { statement. }\end{array}$ & $\begin{array}{l}\text { Indirect } \quad \text { speech act: } \\
\text { representative/assertive, concluding. }\end{array}$ & Social management. \\
\hline 4 & 67 & $\begin{array}{l}\text { Rachel: And then I } \\
\text { got really freaked } \\
\text { out, and that's } \\
\text { when it hit me: how } \\
\text { much Barry looks } \\
\text { like Mr. Potato } \\
\text { Head. }\end{array}$ & Teasing. & $\begin{array}{l}\text { Indirect speech act: expressive, } \\
\text { regretting, } \\
\text { describing. }\end{array}$ & Social management. \\
\hline 4 & 75 & $\begin{array}{l}\text { Rachel: Ooh, I was } \\
\text { kinda hoping that } \\
\text { wouldn't be an } \\
\text { issue... }\end{array}$ & Blunder. & $\begin{array}{l}\text { Indirect speech act: expressive, } \\
\text { apologizing. }\end{array}$ & Social management. \\
\hline 4 & 84 & $\begin{array}{l}\text { Phoebe, Ross, } \\
\text { Chandler, and Joey: } \\
\text { Push her down the } \\
\text { stairs! Push her } \\
\text { down the stairs! } \\
\text { Push her down the } \\
\text { stairs! }\end{array}$ & Chain. & $\begin{array}{l}\text { Direct speech act: expressive, } \\
\text { encouraging. }\end{array}$ & Social management. \\
\hline 5 & 95 & $\begin{array}{l}\text { Rachel: Well, maybe } \\
\text { that's my decision. } \\
\text { Well, maybe I don't } \\
\text { need your money. } \\
\text { Wait!! Wait, I said } \\
\text { maybe!! }\end{array}$ & $\begin{array}{l}\text { Overstatement } \\
\text { and blunder. }\end{array}$ & $\begin{array}{ll}\text { Indirect } \quad \text { speech } & \text { act: } \\
\text { representative/assertive, claiming } & \text { and } \\
\text { asserting, expressive, regretting. } & \end{array}$ & Social management. \\
\hline 5 & 99 & $\begin{array}{l}\text { Phoebe: } \quad \text { (sings) } \\
\text { Raindrops on roses }\end{array}$ & Chain. & $\begin{array}{l}\text { Indirect speech act: expressive, } \\
\text { comforting. }\end{array}$ & Social management. \\
\hline
\end{tabular}




\begin{tabular}{|c|c|c|c|c|c|}
\hline & & $\begin{array}{l}\text { and rabbits and } \\
\text { kittens, (Rachel and } \\
\text { Monica turn to look } \\
\text { at her.) bluebells } \\
\text { and sleighbells and- } \\
\text { something with } \\
\text { mittens... La la la } \\
\text { la...something and } \\
\text { noodles } \\
\text { string. }\end{array}$ & & & \\
\hline 6 & 129 & $\begin{array}{l}\text { Chandler: I'm sorry, } \\
\text { I didn't catch your } \\
\text { name. Paul, was it? }\end{array}$ & $\begin{array}{l}\text { Teasing and } \\
\text { irony. }\end{array}$ & $\begin{array}{l}\text { Indirect } \quad \text { speech } \quad \text { act: } \\
\text { representative/assertive, pretending. }\end{array}$ & Social management. \\
\hline 6 & 131 & $\begin{array}{l}\text { Phoebe: Ooh, I just } \\
\text { pulled out four } \\
\text { eyelashes. } \\
\text { can't be good. }\end{array}$ & $\begin{array}{l}\text { Understatement } \\
\text { and double } \\
\text { entendres. }\end{array}$ & $\begin{array}{l}\text { Indirect speech } \\
\text { representative/assertive, predicting. }\end{array}$ & Social management. \\
\hline 7 & 139 & $\begin{array}{l}\text { Chandler: (deadpan) } \\
\text { Yes, and we're very } \\
\text { excited about it. }\end{array}$ & Irony. & $\begin{array}{l}\text { Indirect speech } \quad \text { act: } \\
\text { representative/assertive, informing. }\end{array}$ & Social management. \\
\hline 8 & 157 & Ross: You guys. & $\begin{array}{l}\text { Clever reply to } \\
\text { serious } \\
\text { statement. }\end{array}$ & $\begin{array}{l}\text { Direct } \quad \text { speech } \\
\text { representative/assertive, answering. }\end{array}$ & Social management. \\
\hline 9 & 185 & $\begin{array}{l}\text { Joey: There's lots of } \\
\text { flavors out there. } \\
\text { There's Rocky } \\
\text { Road, and Cookie } \\
\text { Dough, and Bing! } \\
\text { Cherry Vanilla. } \\
\text { You could get 'em } \\
\text { with Jimmies, or } \\
\text { nuts, or whipped } \\
\text { cream! This is the } \\
\text { best thing that ever } \\
\text { happened to you! } \\
\text { You got married, } \\
\text { you were, like, } \\
\text { what, eight? } \\
\text { Welcome back to } \\
\text { the world! Grab a } \\
\text { spoon! }\end{array}$ & $\begin{array}{l}\text { Teasing and } \\
\text { transformation } \\
\text { of frozen } \\
\text { expression. }\end{array}$ & $\begin{array}{l}\text { Indirect speech act: expressive, } \\
\text { recommending. }\end{array}$ & $\begin{array}{l}\text { Mediation andsocial } \\
\text { management. }\end{array}$ \\
\hline 9 & 188 & $\begin{array}{l}\text { Chandler: Stay out } \\
\text { of my freezer! }\end{array}$ & $\begin{array}{l}\text { Transformation } \\
\text { of frozen } \\
\text { expression. }\end{array}$ & Indirect speech act: directive, warning. & Social management. \\
\hline
\end{tabular}




\begin{tabular}{|c|c|c|c|c|c|}
\hline 10 & 198 & $\begin{array}{l}\text { Monica: (spitting } \\
\text { out her drink in } \\
\text { shock) Oh God, oh } \\
\text { God, I am sorry... I } \\
\text { am so sorry... }\end{array}$ & $\begin{array}{l}\text { Unintentional } \\
\text { humour/ } \\
\text { accidental } \\
\text { physical } \\
\text { humour. }\end{array}$ & ـ. & \\
\hline 11 & 224 & $\begin{array}{l}\text { Chandler: Hi, Paul, } \\
\text { is it? }\end{array}$ & Sarcasm. & $\begin{array}{l}\text { Indirect speech act: expressive, } \\
\text { criticizing. }\end{array}$ & Social management. \\
\hline 12 & 246 & $\begin{array}{l}\text { Rachel: I can see } \\
\text { that. You look like } \\
\text { you slept with a } \\
\text { hanger in your } \\
\text { mouth. }\end{array}$ & Teasing. & $\begin{array}{l}\text { Indirect speech act: expressive, } \\
\text { criticizing. }\end{array}$ & Social management. \\
\hline 14 & 282 & $\begin{array}{l}\text { Rachel: Are you } \\
\text { kidding? I'm } \\
\text { trained for nothing! } \\
\text { I was laughed out of } \\
\text { twelve interviews } \\
\text { today. }\end{array}$ & $\begin{array}{l}\text { Self- } \\
\text { deprecation. }\end{array}$ & $\begin{array}{l}\text { Indirect speech act: representative/ } \\
\text { assertive, denying. }\end{array}$ & Social management. \\
\hline 15 & 297 & $\begin{array}{l}\text { Rachel: I know that. } \\
\text { That's why I was } \\
\text { getting married. }\end{array}$ & $\begin{array}{l}\text { Clever reply to } \\
\text { serious } \\
\text { statement. }\end{array}$ & $\begin{array}{l}\text { Indirect speech act: expressive, } \\
\text { regretting. }\end{array}$ & Social management. \\
\hline
\end{tabular}

Table (4.2) The Percentages of the American Humour Forms

\begin{tabular}{|l|l|l|l|}
\hline No. & Forms of Humour & $\begin{array}{l}\text { The Number of } \\
\text { their Occurrence }\end{array}$ & Percentages \\
\hline 1. & Jokes & 0 & $0 \%$ \\
\hline 2. & Irony & 2 & $4.87 \%$ \\
\hline 3. & Satire & 0 & $0 \%$ \\
\hline 4. & Sarcasm & 1 & $2.43 \%$ \\
\hline 5. & Overstatement & 2 & $4.87 \%$ \\
\hline 6. & Understatement & 1 & $2.43 \%$ \\
\hline 7. & Self-deprecation & 4 & $9.75 \%$ \\
\hline 8. & Teasing & 5 & $12.19 \%$ \\
\hline 9. & Replies to rhetorical questions & 0 & $0 \%$ \\
\hline 10. & Clever replies to serious statement & 5 & $12.19 \%$ \\
\hline 11. & Double entendres & 1 & $2.43 \%$ \\
\hline 12. & Transformations of frozen expression & 2 & $4.87 \%$ \\
\hline 13. & Pun & 0 & $0 \%$ \\
\hline 14. & Unintentional humour/accidental physical humour & 2 & $4.87 \%$ \\
\hline 15. & Unintentional humour/accidental linguistic humour & 0 & $0 \%$ \\
\hline 16. & Banter & 6 & $14.63 \%$ \\
\hline
\end{tabular}




\begin{tabular}{|l|l|l|l|}
\hline 17. & Blunder & 3 & $7.31 \%$ \\
\hline 18 & Chain & 2 & $4.87 \%$ \\
\hline 19. & Freudian slip & 1 & $2.43 \%$ \\
\hline 20. & Mistaken identity & 2 & $4.87 \%$ \\
\hline 21. & Relapse & 1 & $2.43 \%$ \\
\hline 22. & Repartee & 0 & $0 \%$ \\
\hline
\end{tabular}

As it is obvious from the table above, the American characters use banter more than the other types of humour. So, the type of humour which is banter exceeds and domains the other types of humour. It occurs (6) times in the American sitcom and the percentage of it is (14.63\%). This reveals that the American characters exchange teasing among themselves to create humour. Teasing and clever replies to serious statement are used more frequent after banter. They occur (5) times, and their percentage is (12.19\%) because the characters like to make fun of each other's look, habit and characteristics without offending each other. In addition, they like to use wit, incompatible and senseless replies to create humour. After that, self-deprecation is used by the characters to talk about their past bad experiences, to make themselves as the object of humour and to make the audience know them. The number of self-deprecation's occurrences is (4) times and takes (9.75\%). Blunder occurs afterwards and scores (3) and its percentage is (7.31\%). Irony, overstatement, transformations of frozen expression, accidental physical humour, chain and mistaken identity score (2) and their percentage is $(4.87 \%)$. Then, sarcasm, understatement, double entendres, Freudian slip, and relapse occur one time and their percentage is $(2.43 \%)$. Meanwhile jokes, satire, replies to rhetorical questions, pun, accidental linguistic humour, and repartee did not occur in the sitcom.

The strategy used to create humour is having a tendency towards indirect speech acts more than direct speech acts. This is exhibited in the table below:

Table (4.4) The Percentages of Direct and Indirect Speech Acts in Creating American Humour

\begin{tabular}{|l|l|l|l|}
\hline No. & Strategy Used & $\begin{array}{l}\text { The Number of their } \\
\text { Occurrence }\end{array}$ & Percentages \\
\hline 1. & Direct speech acts & 5 & $17.85 \%$ \\
\hline 2. & Indirect speech acts & 23 & $82.14 \%$ \\
\hline
\end{tabular}

Clearly, indirect speech acts score (23) times with (82.14\%) percentage which reveals that the characters utilize utterances with specific speech act and perform another. However, direct speech acts score (5) times and (17.85\%) percentage.

The final item used in analyzing the data is the function of humour. One can check the four functions of humour with their percentages in the table below: 


\section{Table (4.3) The Percentages of American Humour Functions}

From this table, one can notice how social management scores higher than the other functions of humour. It scores (27) times with $(87.09 \%)$ percentage because the characters are friends and they use humour to create or strengthen group interaction. They use social management to embarrass or intimidate the group members, to focus on taboos and unaccepted behaviour, to search attention, to create a mutual laughter, to initiate something, to end something, to pass, to shift a topic, to check, to establish attention and understanding, to use cleverness, to repair a bad situation and to enhance group harmony. Decommitment and mediation register (2) times and $(6.45 \%)$ percentage because the character use humour to mediate a particular situation and to know unrevealed information by asking indirect questions. Defunctionalization did not occur in the sitcom.

\subsection{The Analysis of the British Sitcom 'The Vicar of Dibley}

\section{Season 1}

Episode 1: Arrival

Table (4.5) The Analysis of Humour in 'The Vicar of Dibley'

\begin{tabular}{|l|l|l|l|l|l|}
\hline P. & L. & Data & $\begin{array}{l}\text { Form of } \\
\text { Humour }\end{array}$ & Strategy Used & $\begin{array}{l}\text { Function } \\
\text { Humour }\end{array}$ \\
\hline
\end{tabular}

\begin{tabular}{|c|c|c|c|c|c|c|c|}
\hline \multicolumn{2}{|c|}{ No. } & \multicolumn{2}{|l|}{ Functions of Humour } & \multicolumn{2}{|c|}{$\begin{array}{l}\text { The Number of their } \\
\text { Occurrence }\end{array}$} & \multicolumn{2}{|c|}{ Percentages } \\
\hline \multicolumn{2}{|l|}{1.} & \multicolumn{2}{|l|}{ Social management } & \multicolumn{2}{|c|}{27} & \multicolumn{2}{|c|}{$87.09 \%$} \\
\hline \multicolumn{2}{|l|}{2.} & \multicolumn{2}{|l|}{ Decommitment } & \multicolumn{2}{|c|}{2} & \multicolumn{2}{|c|}{$6.45 \%$} \\
\hline \multicolumn{2}{|c|}{3.} & \multicolumn{2}{|l|}{ Mediation } & \multicolumn{2}{|c|}{2} & \multicolumn{2}{|c|}{$6.45 \%$} \\
\hline \multicolumn{2}{|c|}{4.} & \multicolumn{2}{|l|}{ Defunctionalization } & \multicolumn{2}{|l|}{0} & \multicolumn{2}{|c|}{$0 \%$} \\
\hline 1 & 11 & $\begin{array}{l}\text { REVEREND POTTLE: And } \\
\text { we especially ask you to } \\
\text { remember the Queen who } \\
\text { has been having trouble with } \\
\text { her piles again. And Mrs } \\
\text { Sinclair-Wilson and all her } \\
\text { family. }\end{array}$ & $\begin{array}{l}\text { Blunder, } \\
\text { mistaken identit } \\
\text { and relapse. }\end{array}$ & & $\begin{array}{l}\text { Direct speech } \\
\text { expressive, praying. }\end{array}$ & & Social management. \\
\hline 3 & 32 & $\begin{array}{l}\text { JIM: Ah, no, no, no, no, no, } \\
\text { no, yes. Just one thing. If } \\
\text { that's all right. }\end{array}$ & $\begin{array}{l}\text { Overstatement } \\
\text { and cleve } \\
\text { replies to seriou } \\
\text { statement. }\end{array}$ & & $\begin{array}{l}\text { Direct speech } \\
\text { representative/assert } \\
\text { denying, direct } \\
\text { requesting. }\end{array}$ & & Social management. \\
\hline
\end{tabular}




\begin{tabular}{|c|c|c|c|c|c|}
\hline 3 & 58 & $\begin{array}{l}\text { OWEN: I've nothing against } \\
\text { Prince Edward, though I } \\
\text { don't usually trust bald } \\
\text { blokes. I'm just surprised } \\
\text { though that we don't start with } \\
\text { the Reverend's death }\end{array}$ & Teasing. & $\begin{array}{l}\text { Direct speech act: } \\
\text { representative/assertive, } \\
\text { denying, expressive, } \\
\text { criticizing. }\end{array}$ & Social management. \\
\hline 5 & 97 & $\begin{array}{l}\text { DAVID: But then I think it } \\
\text { would be hard to find anyone } \\
\text { older... without actually } \\
\text { recruiting a member of the } \\
\text { Rolling Stones. }\end{array}$ & Joke. & $\begin{array}{l}\text { Direct speech act: } \\
\text { expressive, joking. }\end{array}$ & Social management. \\
\hline 7 & 9 & $\begin{array}{l}\text { DAVID: No thank you. } \\
\text { Anchovy and peanut butter } \\
\text { not quite my cup of tea. }\end{array}$ & $\begin{array}{l}\text { Transformation } \\
\text { of frozen } \\
\text { expression and } \\
\text { clever replies to } \\
\text { serious } \\
\text { statement. }\end{array}$ & $\begin{array}{l}\text { Indirect speech act: } \\
\text { commissive, refusing. }\end{array}$ & Social management. \\
\hline 13 & 8 & $\begin{array}{l}\text { JIM: That's right. I mean, } \\
\text { look at traffic lights. Well, if } \\
\text { they didn't change there'd be } \\
\text { terrible congestion wouldn't } \\
\text { there? }\end{array}$ & $\begin{array}{l}\text { Replies to } \\
\text { rhetorical } \\
\text { questions and } \\
\text { mistaken } \\
\text { identity. }\end{array}$ & $\begin{array}{l}\text { Indirect speech act: } \\
\text { representative/ } \\
\text { assertive, affirming. }\end{array}$ & Social management. \\
\hline 14 & 27 & $\begin{array}{l}\text { ALICE:Oh - me! Thickness! } \\
\text { (She points her fingers at her } \\
\text { forehead, like a gun.) Pow! }\end{array}$ & $\begin{array}{l}\text { Self-deprecation } \\
\text { and relapse. }\end{array}$ & $\begin{array}{l}\text { Indirect speech act: } \\
\text { representative/ } \\
\text { assertive, concluding, } \\
\text { expressive, criticizing. }\end{array}$ & Mediation. \\
\hline 17 & 26 & $\begin{array}{l}\text { OWEN: Sorry I'm late - it's } \\
\text { like the big ride at Alton } \\
\text { Towers in my innards. }\end{array}$ & $\begin{array}{l}\text { Overstatement } \\
\text { and banter. }\end{array}$ & $\begin{array}{l}\text { Direct speech act: } \\
\text { representative/ } \\
\text { assertive, describing, }\end{array}$ & Social management. \\
\hline
\end{tabular}




\begin{tabular}{|c|c|c|c|c|c|}
\hline & & & & expressive, excusing. & \\
\hline 17 & 37 & $\begin{array}{l}\text { GERALDINE: Hugo - } \\
\text { another stunning tie; girls } \\
\text { just aren't safe are they? }\end{array}$ & $\begin{array}{l}\text { Irony and } \\
\text { teasing. }\end{array}$ & $\begin{array}{l}\text { Indirect speech act: } \\
\text { expressive, criticizing. }\end{array}$ & $\begin{array}{l}\text { Mediation and social } \\
\text { management. }\end{array}$ \\
\hline
\end{tabular}

Table (4.6) The Percentages of the British Humour Forms

\begin{tabular}{|c|c|c|c|}
\hline No. & Forms of Humour & $\begin{array}{l}\text { The Number of } \\
\text { their Occurrence }\end{array}$ & Percentages \\
\hline 1. & Jokes & 1 & $5.88 \%$ \\
\hline 2. & Irony & 1 & $5.88 \%$ \\
\hline 3. & Satire & 0 & $0 \%$ \\
\hline 4. & Sarcasm & 0 & $0 \%$ \\
\hline 5. & Overstatement & 2 & $11.76 \%$ \\
\hline 6. & Understatement & 0 & $0 \%$ \\
\hline 7. & Self-deprecation & 1 & $5.88 \%$ \\
\hline 8. & Teasing & 2 & $11.76 \%$ \\
\hline 9. & Replies to rhetorical questions & 1 & $5.88 \%$ \\
\hline 10. & Clever replies to serious statement & 2 & $11.76 \%$ \\
\hline 11. & Double entendres & 0 & $0 \%$ \\
\hline 12. & Transformations of frozen expression & 1 & $5.88 \%$ \\
\hline 13. & Pun & 0 & $0 \%$ \\
\hline 14. & Unintentional humour/accidental physical humour & 0 & $0 \%$ \\
\hline 15. & Unintentional humour/accidental linguistic humour & 0 & $0 \%$ \\
\hline 16. & Banter & 1 & $5.88 \%$ \\
\hline 17. & Blunder & 1 & $5.88 \%$ \\
\hline 18 & Chain & 0 & $0 \%$ \\
\hline 19. & Freudian slip & 0 & $0 \%$ \\
\hline 20. & Mistaken identity & 2 & $11.76 \%$ \\
\hline 21. & Relapse & 2 & $11.76 \%$ \\
\hline 22. & Repartee & 0 & $0 \%$ \\
\hline
\end{tabular}

Overstatement, teasing, clever replies to serious statement, mistaken identity, and relapse score (2) and their percentage is $(11.76 \%)$ because the British characters like to exaggerate, to make fun of each other's look, habit and characteristics without offending each other, and to use wit. They also use mistaken identity when they are mistaken between things or persons. Jokes, irony, self-deprecation, replies to rhetorical questions, transformations of frozen expression, banter and blunder occur one time and their percentage is $(5.88 \%)$. The rest types of humour did not occur in the sitcom.

The strategy used to create humour is having a tendency towards direct speech acts more than indirect speech acts. This is exhibited in the table below: 
Table (4.7) The Percentages of Direct and Indirect Speech Acts in Creating British Humour

\begin{tabular}{|l|l|l|l|}
\hline No. & Strategy Used & $\begin{array}{l}\text { The Number of their } \\
\text { Occurrence }\end{array}$ & Percentages \\
\hline 1. & Direct speech acts & 5 & $55.55 \%$ \\
\hline 2. & Indirect speech acts & 4 & $44.44 \%$ \\
\hline
\end{tabular}

Clearly, direct speech acts score (5) times with (55.55\%) percentage which reveals that the characters utilize utterances with specific speech act and perform the same. However, indirect speech acts score (4) times and (44.44\%) percentage.

The final item used in analyzing the data is the function of humour. One can check the four functions of humour with their percentages in the table below:

Table (4.8) The Percentages of British Humour Functions

\begin{tabular}{|l|l|l|l|}
\hline No. & Functions of Humour & $\begin{array}{l}\text { The Number of their } \\
\text { Occurrence }\end{array}$ & Percentages \\
\hline 1. & Social management & 8 & $80 \%$ \\
\hline 2. & Decommitment & 0 & $0 \%$ \\
\hline 3. & Mediation & 2 & $20 \%$ \\
\hline 4. & Defunctionalization & 0 & $0 \%$ \\
\hline
\end{tabular}

From this table, one can notice how social management scores higher than the other functions of humour. It scores (8) times with $(80 \%)$ percentage because the characters use humour to create or strengthen group interaction. They use social management to embarrass or intimidate the group members, to focus on taboos and unaccepted behaviour, to search attention, to create a mutual laughter, to initiate something, to end something, to pass, to shift a topic, to check, to establish attention and understanding, to use cleverness, to repair a bad situation and to enhance group harmony. Mediation register (2) times and (20\%) percentage because the character use humour to mediate a particular situation and to know unrevealed information by asking indirect questions. Decommitment and defunctionalization did not occur in the sitcom.

\subsection{The Findings of the American Humour Vs the Findings of the British Humour}

From the results mentioned above, it seems obvious that the forms (types) of humour in the American situation comedy 'Friends' are more intensive than the forms of humour found in the British sitcom 'The Vicar of Dibley'. The American sitcom scores (41) times for the types of humour, while the British one scores (17) times. Direct and indirect speech acts are (28) in the American sitcom and (9) in the British sitcom. The functions of humour are (31) in the American sitcom, while in the British sitcom, it is (10). 


\section{CONCLUSIONS}

After finishing the results of the two situation comedies, the researcher is going to draw conclusions by taking into account the hypotheses of the study and the results of the analysis. Firstly, the first hypothesis states that 'there is a relation between humour and speech acts'.

There is also a relation between humour and speech acts because humour sometimes indicates direct or indirect speech act. So, in order to know the strategy used in creating humour, one has to categorize the types of humour into direct or indirect speech acts. As a result, the first hypothesis is verified. The second hypothesis says that 'humour is created by violating the maxims of Grice rather than flouting'. From the analysis and the results showed in the previous chapter, it seems quite clear that this hypothesis is rejected or invalid because flouting scores more than violation in both situation comedies

The second hypothesis states that 'humour is being used more among the British people rather than the American ones'. Actually American people uses humour more intensively than British people do because American humour scores (41) times, but British humour scores (17) times. This means that the hypothesis is rejected.

\section{BIBLIOGRAPHY}

Anand, K. M. (2014). 'Discourse Analysis of Indian Parliamentary Debates with Special Reference to Wit and Humour'. Aundh: Savitribai Phule Pune University.

Attardo, S. 1994. Linguistic Theories of Humor. New York: Mouton de Gruyter.

Audrieth, A. L. (1998). The Art of Using Humor in Public Speaking. Retrieved July 28, 2008, from http://www:squiresail.com/auh.html\#types.

Buijzen, M., \& Valkenburg, P. M. (2004). Developing a Typology of Humor in Audiovisual Media. Media Psychology, $6(2)$. https://doi.org/10.1207/s1532785xmep0602_2

Chadwick, D. D. (2018). Investigating Humor in Social Interaction in People with Intellectual Disabilities: A
Systematic Review of the Literature. United Kingdom: University of Wolverhampton.

Crystal, D. (2011). A Dictionary of Linguistics and Phonetics. $\left(6^{\text {th }}\right.$ ed.). United Kingdom: Blackwell Publishing.

Ermida, I. (2008). The Language of Comic Narratives, Humor Construction in Short Stories.

Gruner, C. R. (1997). The Game of Humor: A Comprehensive Theory of Why We Laugh. Transaction Publishers.

Keith, N. Z. (2015). Engaging in Social Partnerships: Democratic Practices for Campus-community Partnerships. New York: Routledge.

Lefcourt, H. (2001). Humor: The Psychology of Living Buoyantly. NY: Kluwer/Plenum 2001.

Long, D. L., \& Graesser, A. C. (1988). Wit and Humor in Discourse Processing. Discourse Processes.

Lynch, O. H. (2002). Humorous Communication: Finding a Place for Humor in Communication Research. Wiley Online Library.

Martin, R. A. (2007). The Psychology of Humor: An Integrative Approach (2nd ed.). Burlington, MA: Elsevier academic press.

Martin, R. A. (2010). The Psychology of Humor: An Integrative Approach (3rd ed.). Burlington, US: Academic press.

Mulder, M. P., \& Nijholt, A. (2002). Humour Research: State of the Art. Netherlands: Univeristy of Twente.

Nilsen, A. P. \& Nilsen, D. L. F. (2000). Encyclopedia of $20^{\text {th }}$-Century American Humor. Indian University.

Schaeffer, N. (1981). The Art of Laughter. NY: Columbia University Press.

Van Dijk, T. A. (1985). Handbook of Discourse Analysis: Discourse Analysis in Society. London: Sage Publications Ltd.

White, E. B. (1977). Essays of E. B. White. NY: Harper \& Row. 
Widdowson, H. G. (2007). Discourse Analysis. Oxford: Oxford University Press.

Wood, L. A., \& Kroger, R. O. (2000). Doing Discourse Analysis: Methods for Studying Action in Talk and Text. US: Sage Publications.

Wyer, R. S., \& Collins, J. E. (1992). A theory of humor elicitation. Psychological Review, 99(4). https://doi.org/10.1037/0033-295X.99.4.663.

Yule, George (1996). Pragmatics. Oxford: Oxford University Press. 